\title{
The Polish School of Argumentation: A Manifesto
}

\author{
Katarzyna Budzynska • Michal Araszkiewicz • Barbara Bogołębska • Piotr Cap • \\ Tadeusz Ciecierski • Kamila Debowska-Kozlowska • Barbara Dunin-Kęplicz • \\ Marcin Dziubiński • Michał Federowicz • Anna Gomolińska • \\ Andrzej Grabowski • Teresa Holówka • Lukasz Jochemczyk • \\ Magdalena Kacprzak • Pawel Kawalec • Maciej Kielar • Andrzej Kisielewicz • \\ Marcin Koszowy • Robert Kublikowski • Piotr Kulicki • Anna Kuzio • \\ Piotr Lewiński - Jakub Z. Lichański • Jacek Malinowski • Witold Marciszewski • \\ Edward Nieznański • Janina Pietrzak • Jerzy Pogonowski • \\ Tomasz A. Puczyłowski • Jolanta Rytel • Anna Sawicka • Marcin Selinger • \\ Andrzej Skowron • Joanna Skulska • Marek Smolak • Małgorzata Sokól • \\ Agnieszka Sowińska • Piotr Stalmaszczyk • Tomasz Stawecki • \\ Jarosław Stepaniuk • Alina Strachocka • Wojciech Suchoń • \\ Krzysztof Szymanek • Justyna Tomczyk • Robert Trypuz $\cdot$ Kazimierz Trzęsicki • \\ Mariusz Urbański • Ewa Wasilewska-Kamińska • Krzysztof A. Wieczorek • \\ Maciej Witek • Urszula Wybraniec-Skardowska • Olena Yaskorska • \\ Maria Załęska • Konrad Zdanowski • Tomasz Żurek \\ Published online: 9 August 2014 \\ (C) The Author(s) 2014. This article is published with open access at Springerlink.com
}

\begin{abstract}
Building on our diverse research traditions in the study of reasoning, language and communication, the Polish School of Argumentation integrates various disciplines and institutions across Poland in which scholars are dedicated to understanding the phenomenon of the force of argument. Our primary goal is to craft a methodological programme and establish organisational infrastructure: this is
\end{abstract}

K. Budzynska $(\bowtie) \cdot J$. Malinowski $\cdot$ O. Yaskorska

Department of Logic and Cognitive Science, Institute of Philosophy and Sociology,

Polish National Academy of Sciences, ul. Nowy Świat 72, p. 225, 00-330 Warsaw, Poland

e-mail: budzynska.argdiap@gmail.com

\section{Federowicz}

Research Group on Sociology of Politics and Economy, Institute of Philosophy and Sociology,

Polish National Academy of Sciences, Warsaw, Poland

M. Araszkiewicz · A. Grabowski

Department of Legal Theory, Jagiellonian University in Krakow, Krakow, Poland

W. Suchón

Institute of Philosophy, Jagiellonian University in Krakow, Krakow, Poland

B. Bogołębska

Department of Journalism and Social Communication \& Polish Rhetorical Society,

University of Łódź, Łódź, Poland 
the first key step in facilitating and fostering our research movement, which joins people with a common research focus, complementary skills and an enthusiasm to work together. This statement-the Manifesto-lays the foundations for the research programme of the Polish School of Argumentation.

Keywords Force of argument - Reason - Trust · Cognition ·

Interdisciplinary approach $\cdot$ Argument studies in Poland

\section{Introduction}

The Polish School of Argumentation brings together and integrates the richness and breadth which argument studies have developed over the last ten years within many disciplines and numerous institutions across Poland. The common motif of our approach can be best described as the force of argument-the logical force of validity, the rhetorical force of persuasiveness, the pragmatic force of communicative intentions, and many other types of force, with a particular focus on reason, trust and cognition (see Sect. 2). Bearing in mind the challenging of integrating many different research perspectives and disciplines, we devote careful attention to crafting a methodological programme which will provide a strong and reliable foundation for the research of the Polish School of Argumentation (Sect. 3).

The rich diversity of approaches to argumentation in Poland is striking, encompassing philosophy, logic, linguistics, rhetoric, social science, psychology, cognitive science, AI and law (see Sect. 5, and also (van Eemeren et al. 2015)). One reason for this diversity might be found in our strong tradition of studying the phenomena of reasoning, language and communication. This is particularly well

P. Cap · P. Stalmaszczyk

Institute of English Studies, University of Łódź, Łódź, Poland

K. Debowska-Kozlowska $\cdot$ M. Kielar

Department of Pragmatics of English, Faculty of English,

Adam Mickiewicz University in Poznań, Poznań, Poland

J. Pogonowski

Department of Applied Logic, Adam Mickiewicz University in Poznań, Poznań, Poland

M. Smolak

Faculty of Law and Administration, Adam Mickiewicz University in Poznań, Poznań, Poland

M. Urbański

Institute of Psychology, Adam Mickiewicz University in Poznań, Poznań, Poland

T. Ciecierski · T. Hołówka · T. A. Puczyłowski

Institute of Philosophy, University of Warsaw, Warsaw, Poland

B. Dunin-Kęplicz · M. Dziubiński · A. Strachocka

Institute of Informatics, University of Warsaw, Warsaw, Poland 
reflected in the research of the Lvov-Warsaw School, and then its successors in Artificial Intelligence and legal theory, as well as in the studies of Polish rhetoricians (Sect. 4, see also (Groarke 2013)). Because of the natural strong resemblance between reasoning, language and communication and the phenomenon of argumentation, Polish researchers became increasingly interested in exploring links between their investigations and the flourishing area of the contemporary theory of argument. Now that argument studies have matured in Poland, we are ready to establish a network of close cooperation and organisational infrastructure to facilitate and foster our research movement (Sect. 6).

\title{
2 Force of Argument: Reason, Trust and Cognition
}

The common motif in the research of the Polish School of Argumentation is the force of argument. We focus on its structural, institutional and mental aspects. The basic assumption is that argumentation is a reason-guided activity. In other words, we take its structure to be shaped first by rules and principles that should be studied with the use of logic. Arguments, however, also contribute to many institutional aspects of social reality, and in particular, affect and strengthen the relation of trust between participants in public life. Finally, we take into account the mental determinants of argumentative practice - in other words, the fact that the way real arguments function depends on the cognitive architecture of the human mind.

In the classical (i.e. logical) tradition, the force of an argument is interpreted as the validity of an argument. The problem of argument evaluation, which is central to argumentation theory, deals with questions such as these: How strong is the argument? To what degree is the conclusion justified by the premises? To what

ŁukaszJochemczyk · J. Pietrzak

Faculty of Psychology, University of Warsaw, Warsaw, Poland

\section{J. Z. Lichański}

Institute of Applied Polish Studies \& Polish Rhetorical Society, University of Warsaw, Warsaw, Poland

\author{
A. Skowron \\ Institute of Mathematics, University of Warsaw, Warsaw, Poland \\ T. Stawecki \\ Faculty of Law and Administration, University of Warsaw, Warsaw, Poland \\ E. Wasilewska-Kamińska \\ Faculty of Education, University of Warsaw, Warsaw, Poland
}

M. Załęska

Department of Modern Languages \& Polish Rhetorical Society,

University of Warsaw, Warsaw, Poland

\section{Federowicz}

Educational Research Institute, Warsaw, Poland 
degree should I believe a thesis given the reasons you give to believe it? The ability to provide answers to these questions is fundamental to a proper understanding of cognitive processes, growth of knowledge, and progress in science, as well as for elaborating on criteria for discursive practice in politics, law, education, economics and other forms of public life.

Natural argumentation is, however, a highly complex phenomenon and thus logic should be supported by other disciplines so that the issues mentioned above can be approached in an insightful and multifaceted manner. In particular, arguments are expressed in natural language through an assortment of communicative intentions, which raises further questions: How do people express reasons in language? What types of illocutionary acts and rhetorical techniques do they use in argumentative contexts? What are the institutional and ethotic preconditions for making successful argumentative acts? Arguments are also exchanged in a complex process of communication, which leads to problems such as these: What are the rules of rational discussion? How do we play dialogue games? Furthermore, once we begin to consider the dialogical context of argumentation, the problem of persuasion emerges in a natural way as well: How does our trust in a speaker influence what we decide to believe? What role does persuasion and argumentation play in our cognition? In order to pursue and explore different questions triggered by the study of the complex realm of arguing, the Polish School of Argumentation integrates various complementary theories, perspectives, approaches and disciplines.

\section{Methodological Programme for the Interdisciplinary Approach}

The interdisciplinary approach adopted by the Polish School of Argumentation aims to integrate research results from different disciplines describing various aspects and determinants of argumentative practice (Budzynska et al. 2012; Stalmaszczyk 2013). We bring together a variety of perspectives from philosophy, logic,

\section{A. Gomolińska}

Institute of Informatics, University of Bialystok, Białystok, Poland

\section{Koszowy · W. Marciszewski · K. Trzęsicki}

Department of Logic, Informatics and Philosophy of Science, University of Bialystok, Białystok, Poland

M. Kacprzak · J. Stepaniuk

Faculty of Computer Science, Bialystok University of Technology, Białystok, Poland

P. Kawalec $\cdot$ R. Kublikowski · P. Kulicki · R. Trypuz

Faculty of Philosophy, John Paul II Catholic University of Lublin, Lublin, Poland

\section{A. Kisielewicz}

Institute of Mathematics, University of Wrocław, Wrocław, Polad

P. Lewiński

Department of Applied Linguistics, University of Wrocław, Wrocław, Poland 
linguistics, rhetoric, psychology, cognitive science, AI, law, and other fields that lie within the areas of expertise of our group's members.

Such a challenging diversity necessitates careful selection and elaboration of research methods. The development of a methodologically coherent research programme requires a unified and well-specified conceptual apparatus that can be used to compare theories and data from various disciplines, approaches, and paradigms (see e.g. a dictionary of argumentation theory terminology by Szymanek (2001); in Polish). With such an apparatus in hand one could not only build a comprehensive and multidimensional model of argumentative practice, but also ask new and original research questions that could lead to new research areas and projects.

We claim that methods which deal with real-life data, such as corpus studies and experiments, should be combined with the precision and rigour characteristic of formal and analytical approaches. Theoretical and abstract frameworks offered by disciplines such as philosophy, logic and AI should be systematically confronted, in terms of both inspiration and verification, with the real input provided by such disciplines as linguistics, rhetoric, cognitive science and law.

Consequently, we place increased emphasis on integrating the following: (1) the formal perspective on the modelling of argumentation and dialogues with the informal approach developed by, e.g., pragmatists and speech act theorists; (2) conceptual studies with empirical-oriented research; (3) the construction of theoretical models with their practical application for describing, evaluating and managing real argumentative practices in such domains as public debates, politics, law, education, medical discourse, and so on; and (4) research investigations with

\author{
J. Tomczyk \\ Department of Sociology, University of Wrocław, Wrocław, Poland
}

M. Selinger

Department of Logic and Methodology of Sciences, University of Wrocław, Wrocław, Poland

A. Kuzio

Department of Humanities, University of Zielona Góra, Zielona Góra, Poland

J. Malinowski

Department of Logic, Nicolaus Copernicus University in Toruń, Toruń, Poland

A. Sowińska

Department of English, Nicolaus Copernicus University in Toruń, Toruń, Poland

E. Nieznański

Faculty of Law and Administration, Lazarski University, Warsaw, Poland

J. Rytel

Institute of Psychology, Cardinal Stefan Wyszyński University in Warsaw, Warsaw, Poland

\title{
K. Zdanowski
}

Department of Mathematics and Natural Sciences, Cardinal Stefan Wyszyński University in Warsaw, Warsaw, Poland 
teaching programmes implementing the theoretical developments of the Polish School of Argumentation. This integration is not a unifying synthesis, but an aggregation of mutually irreducible approaches specific to particular disciplines represented by the signatories of the manifesto.

\section{Our Roots}

The main claim with regard to the roots of the Polish School of Argumentation is that its future development may and should be inspired by the diversity of philosophical, logical, computational, linguistic, rhetorical, legal, cognitive, psychological, and educational approaches to language, reasoning and communication which were founded or developed within Polish academia in the 20th century. One important tradition is the logico-methodological legacy of the LvovWarsaw School (LWS), a Polish research movement that was most active from 1895 to 1939 (Woleński 2013). Apart from outstanding achievements in formal logic, the rich legacy of the LWS encompasses a great variety of ideas in epistemology, ontology, philosophy of language, semiotics, philosophy of reasoning, methodology of science, legal theory, ethics and aesthetics.

The philosophical and logical accounts of arguments within the Polish School of Argumentation may be inspired by the works of representatives of the LWS who attempted to solve similar problems to those present in contemporary philosophy of argument (Koszowy and Araszkiewicz 2014): Kazimierz Twardowski (the founder of the School, who postulated precision, rigour and clarity in philosophy), Kazimierz Ajdukiewicz (the key representative of the pragmatic movement within

\footnotetext{
A. Sawicka

Faculty of Computer Science, Polish-Japanese Institute of Information Technology in Warsaw,

Warsaw, Poland

J. Skulska

Institute of Organization and Management, Military University of Technology in Warsaw, Warsaw, Poland
}

M. Sokół

Department of English, University of Szczecin, Szczecin, Poland

M. Witek

Institute of Philosophy, University of Szczecin, Szczecin, Poland

K. Szymanek · K. A. Wieczorek

Department of Logic and Methodology, University of Silesia in Katowice, Katowice, Poland

U. Wybraniec-Skardowska

Group of Logic, Language and Information, Opole University, Opole, Poland

T. Żurek

Institute of Computer Science, Maria Curie-Skłodowska University in Lublin, Lublin, Poland 
the LWS, whose ideas are assessed as strikingly similar to the study of argumentation in North America (Groarke 2013)), and many others, including Tadeusz Czeżowski, Seweryna Łuszczewska-Romahnowa, Tadeusz Kotarbiński, Klemens Szaniawski, and Józef M. Bocheński. Their research postulates include many that are particularly promising for further developments, such as: the conception of logical culture in research and teaching; opposition to irrationalism and insistence on proper justification of accepted propositions; the broad conception of logic, including, but not limited to, deductive reasoning; and an emphasis on proper inference and other knowledge-gaining procedures, such as defining or questioning.

After World War II, the influence of this tradition on Polish philosophy remained particularly strong (Wójcicki 1997), leading, e.g, to the foundation of the journal Studia Logica in 1953 and the Department of Logic (currently the Department of Logic and Cognitive Science) at the Polish Academy of Sciences in 1955-both on the initiative of Kazimierz Ajdukiewicz, as well as the establishment of the Polish Semiotic Society (PTS) in 1968, on the initiative of Jerzy Pelc, and the journal Studies in Logic, Grammar and Rhetoric (SLGR), on the initiative of Witold Marciszewski. Probabilism, with its version of the evaluative Bayesian approach (Ajdukiewicz 1974; Kawalec 2012), is identified (Woleński and Lapointe 2009) as a markedly pluralism-oriented constituent of the Lvov-Warsaw School approach to argumentation with particular emphasis on scientific inferences. In functional logical semiotics, the studies focused on the usage of various types of expressions and the distinction between manner of use (of an expression) and use (of an expression) (Pelc 1969, 1970).

The Lvov-Warsaw School's developments in logic have significantly influenced Polish research in the area of Artificial Intelligence. Strong connections between computational models and argumentation theory can be found in the investigations of multi-agent systems carried out mainly by a group in Warsaw. The representation of autonomous intelligent systems of collaborating agents entails the description of complex interactions such as cooperation, coordination and negotiation. These paradigmatic activities are usually achieved with extensive use of communication. The first step in the research was the synthesis of three approaches: the semi-formal theory of dialogue (Walton and Krabbe 1995), the speech acts theory (Austin 1962; Searle 1969), and Dunin-Kęplicz and Verbrugge's theory of collective motivational attitudes in Beliefs, Desires, Intentions (BDI) systems. This formalism was used to show how to create collective intention through dialogue, mainly persuasion (Dignum et al. 2001) and deliberation (Dunin-Kȩplicz and Verbrugge 2010).

Another important line of research, represented by the Polish School of AI (Skowron et al. 2013), applies methods of rough set theory (Pawlak 1982) and rough-granular computing (Stepaniuk 2008). The school focuses on approximation of and reasoning about vague concepts using complex patterns which can be treated as arguments 'for' or 'against' concepts. Such arguments can also be referred to as the computational building blocks necessary for cognition, following the suggestion of Leslie Valiant (the 2010 Turing award winner). 
The Polish School of Argumentation also builds on the best traditions of legal logic and the theory of legal argumentation developed mainly in Krakow and Poznań. The research in Krakow has been significantly influenced by the methodological postulates of precision, rigour and clarity advanced by the LWS. The special focus has been on issues such as extensional semantics of legal interpretation (Woleński 1972), the burden of argumentation in legal disputes (Gizbert-Studnicki 2010) or the pragma-dialectic account of legal argumentation (Grabowski 1999). Several academics who were educated there continued and popularised this research approach in other institutions in Poland (such as Jerzy Wróblewski, who lived and worked in Łódź (Wróblewski 1992)) and abroad (such as Aleksander Peczenik in Lund, Sweden (Peczenik 1966, 2008)).

In Poznań, argument studies were initiated by Czesław Znamierowski and continued by his students, including Ziembiński (1966), Nowak (1973), Patryas (1988) and Zieliński and Ziembiński (1988). Ziembiński's textbook Practical Logic (Ziembiński 1955) has been printed in twenty-six editions, and as a consequence many Polish lawyers share the approach to logic characteristic of the studies in Poznań.

In parallel to the research of the LWS and its successors, a strong tradition of rhetorical studies has developed in Poland since the sixteenth century (see e.g. (Górski 1559; Konarski 1767)). A recent perspective combines an interest in rhetoric with a professional background in disciplines such as linguistics, literary criticism, discourse analysis, sociology, anthropology, history, or cultural studies (see e.g. (Lichański 2003; Skwara 2006; Barłowska et al. 2011; Załęska 2012) for an overview). As a result, this approach privileges a naturalist, humanist and essentially informal approach to argumentation, the exploration of argumentation through the notion of discourse, and an emphasis on sociocultural features and conventions imposed by specific genres of discourse (Dobrosielski 1957; Mayakowska 1936; Ziomek 1990; Bogołębska 2006). The rhetorical perspective offers insights on heterogeneous factors that shape the actual persuasiveness of natural arguments, complementing the more abstract and formalised approaches to the study of argumentation typical for logic, AI, and computational and cognitive models. In 2001, the rhetorical community established an autonomous organisation, the Polish Rhetorical Society (PTR), and its journal Forum Artis Rhetoricae.

The Polish School of Argumentation builds upon and integrates this variety of traditions in pursuit of a comprehensive and multidimensional model of argumentative practice.

\section{Research Topics}

The combination of the theoretical background of philosophy, logic and AI with the real-data, practical verification of research results in rhetoric, linguistics and law is reflected in the multidisciplinary composition of our group. The research topics of the Polish School of Argumentation reflect its leitmotif of the force of argument. Thus the evaluation of argument force is the central object of interest, initiated in Poland, mainly, by Marciszewski (1994a, b), Hołówka (1998, 2007), Suchoń (2005, 2008) and Tokarz $(1985,1987,2006)$. 
In our approach, various aspects of the evaluation are related to the ideas of reason, cognition and trust. We propose to distinguish three aspects of evaluation, depending on whether the research focuses on (1) the force of argument in itself: research on the rationality and objective value of argumentation (the logicophilosophical aspect); (2) the force of argument with reference to the cognition that an argument can provide: research on the cognitive effectiveness of argumentation (the cognitive and rhetorico-persuasive aspect); or (3) the force of argument with reference to the cognition which an argument can provide, but relating to yet something else, that is, to a certain general goal represented by the idea of agreement between the participants in a discussion: research on the consensual effectiveness of argumentative dialogue based on trust (the pragma-dialectical and social aspect).

Reason The idea of reason is taken up in the study of the logical structure of everyday argumentation, resulting in formal models of it, such as a dialogue system for the identification and elimination of formal fallacies (Yaskorska et al. 2013; Kacprzak and Yaskorska 2014; Kacprzak and Sawicka 2014), probabilistic and inductive models of justification (Kawalec 2003), an account of real premises of argumentation for dynamic epistemic logic (Bryniarski et al. 2011), a description of intelligent agent judgement (Gomolińska 2005), and a model of teleological interpretation of statutory legal rules (Żurek and Araszkiewicz 2013).

We investigate specific types and properties of arguments, e.g. arguments from similarity and slippery slope arguments (Szymanek 2009; Wieczorek 2013), abductive reasoning (Urbański 2009), players' strategies in dialogue games (Kacprzak et al. 2014; Dziubiński and Goyal 2013), the role of definition in argumentation (Kublikowski 2009), and axiological aspects of argumentation (Lewiński 2012; Cap 2013). We are interested in exploring methods of representation and numerical evaluation of argument structures (Pogonowski 2011; Selinger 2014) and in applications of argumentation theory and logic in political discourse (Cap 2013; Skulska et al. 2013) and law (Nieznański 2010; Stawecki 2012). In addition, various software tools supporting analysis of the rational aspects of evaluation have been developed, such as Perseus (Budzynska et al. 2009), Araucaria-PL (Budzynska 2011) or MIZAR (Trybulec 1978).

The research in the area of multi-agent systems initiated in Warsaw (see Sect. 4) has recently evolved towards a proper treatment of incomplete and inconsistent information appearing in dialogue and typically originating from multiple sources of varying credibility, quality or significance. To this end, Dunin-Kęplicz and Strachocka exploit a paraconsistent and nonmonotonic approach to speech acts, argumentation schemes and dialogues (Dunin-Kȩplicz and Strachocka 2013). Rather than reasoning in multi-modal logical systems of high complexity they lean towards querying paraconsistent knowledge bases built upon 4QL, the new paraconsistent 4-valued query language, designed by Małuszyński and Szałas (2013).

Polish authors, however, emphasise that while the role of logical reconstruction of arguments and evaluation of their force is important, it should not be overestimated, especially when applied to everyday reasoning (Kisielewicz 2011) or juristic argumentation (Grabowski 2003; Peczenik 1988; Smolak 2003). The 
latter should rather be understood as a special case of general practical or moral discourse. The phenomenon of non-deductive transformations ('jumps') in the domain of juristic justificatory reasoning (Peczenik and Wróblewski 1985) is an obvious example of reasoning that cannot be fully explained and evaluated on a logical basis.

Trust Our models of dialogue explore the concept of mutual trust between dialogue participants, who are often confined to relying on strict intra-dialogical rules. Issues related to the social and pragmatic aspects of communication are integrated into our research to describe and explain how trust influences the process of argumentation and its outcomes in various domains (e.g. law, politics or education).

The idea of trust is specifically covered by the fields of our research which refer to ethos and pathos-treated as communicative structures independent from logos (Budzynska 2013); parameters of an expert's good reputation, such as solidity and trustworthiness (Załęska 2011); or the role of questions in creating a scientist's image (Sokół 2010). Members of the school investigate argument, dialogue and trust together with their relationship to certain pragmatic and dialectic phenomena, such as conversational implicatures (Puczyłowski 2012), illocutionary context and ethotic felicity conditions (Witek 2013; Budzynska and Witek 2014; Malinowski 2003), and the role of argumentation and deliberation in civil society (Tomczyk 2011).

Cognition The Polish School of Argumentation is also interested in applying cognitive frameworks to elaborate on models of dialogues and argument. The research topics of our group include goals and effects of persuasive dialogues (Debowska-Kozlowska 2014), argument principles and cognitive-pragmatic strategies associated with legitimisation through fear appeals in political discourse (Wybraniec-Skardowska 2010; Cap 2013), links between fallacies and mental models (Wieczorek 2007), the role of cultural scripts in manipulation (Kuzio 2014), and the nature of cognition and research activity in mathematics (Pogonowski 2012).

We use corpus analysis (see, e.g., ArgDB-pl-a Polish online corpus of analysed argumentation, http://argumentacja.pdg.pl/argdbpl/) and experimental studies to explore issues such as critical analysis of values in political discourse (Sowińska 2013; Kielar 2011), dynamics and structure of argumentation in negotiations (Jochemczyk and Nowak 2010), and argumentative skills in preschoolers' narrative discourse (Rytel 2012). We also pursue methods of formalisation of cognitive and rhetoric phenomena such as a logic of questions in a dialogue (Wiśniewski 1996; Urbański 2001), and a formal framework for knowledge management and acquisition (Garbacz et al. 2012).

\section{Organisation and Infrastructure}

Members of the Polish School of Argumentation represent many different disciplines, departments and institutions across Poland. Our goal is to maintain and support this diversity while at the same time developing and actively promoting 
a coherent interdisciplinary network of close cooperation and effective teamwork amongst individual scholars and research groups focusing on the leitmotif of the force of argument.

We place particular stress on strong collaboration with Polish research associations, organisations and groups working in areas related to argument studies, such as the Polish Rhetorical Society (PTR), the Polish Semiotic Society (PTS), the Group of Logic, Language and Information (GLLI), the Polish Pragmatics Association (PPA) and the Polish Association for Logic and Philosophy of Sciences (PTLiFN). We also maintain close ties with the international community through participation in collaborative projects and key conferences, as well as cooperation with various associations and centres for argument studies.

The ArgDiaP organisation (http://argdiap.pl/) provides infrastructure facilitating the networking process and fosters research on argumentation in Poland, including the research of the Polish School of Argumentation. A strong focus is placed on support venues for the exchange of ideas and knowledge transfer, such as conferences, workshops, graduate schools and publishing initiatives. Since 2008, ArgDiaP has organised 11 workshops, at which over 60 papers have been presented, hosting over 50 speakers from 20 leading Polish universities and research institutes and 10 speakers from the US, Canada, Germany, France, the Netherlands, Sweden and the UK. Our special guests have included Frans van Eemeren (Amsterdam), Leo Groarke (Windsor, Canada), Chris Reed (Dundee, UK) and John R. Searle (Berkeley). The Stanford Encyclopedia of Philosophy recognised the ArgDiaP workshops as one of the world's five most important events in the theory of argumentation.

The Interdisciplinary Graduate School on Argumentation and Rhetoric (IGSAR) has been associated with ArgDiaP conferences since 2013. Students first participate in two days of tutorials serving as an introduction to the talks presented at the conference, and then take part in the conference itself. Our long-term mission is to contribute to the establishment of teaching standards by implementing the theoretical development of the School and to support the best educational practices for argumentation theory in Poland (Domański et al. 2012; Wasilewska-Kamińska 2014).

Members of our group are engaged in the organisation and coordination of many other events, such as conferences on Applications of Logic in Philosophy and the Foundations of Mathematics (nineteen editions); Autonomous Agents and Multiagent Systems (AAMAS) (two editions); Intelligent Agent Technology (IAT) (two editions); Alternative Methods of Argumentation in Law (three editions); Philosophy of Language and Linguistics (three editions); and New Developments in Linguistic Pragmatics (six editions); as well as workshops on Formal Approaches to MultiAgent Systems (FAAMAS) (four editions); and Legal Informatics and Legal Information Technology (LIT) (six editions).

In 2009, a publishing platform was established for the Polish School of Argumentation. Since that time our argumentation series has released three special issues dedicated to: major research strands in the philosophy of argument (in its introduction to Informal Logic, the Stanford Encyclopedia of Philosophy comments that it has published an important special issue on the field) (Koszowy 2009); 
computational approaches to argumentation (Koszowy 2011); and pragmatics and dialectics of argument (Budzynska et al. 2014). Contributing authors have included Leila Amgoud (Toulouse), Floris Bex and Jan Albert van Laar (Groningen), J. Anthony Blair, Ralph H. Johnson and Douglas Walton (Windsor, Canada), Frans H. van Eemeren, Bart Garssen and Francisca Snoeck Henkemans (Amsterdam), David Hitchcock (Hamilton, Ontario), Dale Jacquette (Bern, Switzerland), Fabrizio Macagno (Milano), Jim Mackenzie (Sydney), Chris Reed (Dundee, UK), John R. Searle (Berkeley) and Peter Simons (Dublin). Members of and collaborators with our group are engaged in the editorship of several journals including Studies in Logic, Grammar and Rhetoric; Studia Logica; Lodz Papers in Pragmatics; International Review of Pragmatics; and Forum Artis Rhetoricae.

\section{Conclusions}

The Polish School of Argumentation brings together scholars representing a variety of complementary disciplines while sharing the same research focus-to understand the fundamental and complex problem of the force of argument. The movement aims to transform the landscape of argument studies in Poland by supporting a national, interdisciplinary and integrated network closely linked to and collaborating with the international community.

We believe that this integration allows us to go beyond individual research efforts, opening up new and exciting opportunities and perspectives. Our mission is to abide by and adapt to the requirements of modern academia, establish the best practices in research and teaching, and develop a stimulating and advantageous environment for the young generation of the Polish School of Argumentation.

Acknowledgments We gratefully acknowledge the support of the Polish National Science Center for Budzynska, Kacprzak and Koszowy under grant 2011/03/B/HS1/04559, for Dunin-Kęplicz and Strachocka under grant 2011/01/B/ST6/02769, for Jochemczyk and Pietrzak under grant 2011/01/D/ HS6/02264, for Stepaniuk under grant 2012/07/B/ST6/ 01504, for Urbański under grant 2012/04/A/HS1/ 00715 and for Witek under grant 2011/03/B/HS1/00917. We also gratefully acknowledge the support for Kulicki and Trypuz under grant WND-POIG.01.03.01-00-204/09 (partial support) and for Skulska under grant for young researchers RMN 703/2012. The research of Skowron was supported by the Polish National Science Centre: grants DEC-2011/01/B/ ST6/03867, DEC-2011/01/D /ST6/06981, and DEC2012/05/B/ST6/03215 as well as by the Polish National Centre for Research and Development under grants SYNAT No. SP/I/1/77065/10 and PBS2/B9/20/2013.

Open Access This article is distributed under the terms of the Creative Commons Attribution License which permits any use, distribution, and reproduction in any medium, provided the original author(s) and the source are credited.

\section{References}

Ajdukiewicz K. 1974. Pragmatic logic. Trans. O. Wojtasiewicz. Dordrecht: D. Reidel.

Austin, J.L. 1962. How to do things with words. Oxford: Clarendon.

Barłowska, M., I. Bartoszewicz, B. Bogołębska, L. Drong, W. Godzic, J. Jabłońska-Bonca, J. Lichański, M. Lisowska-Magdziarz, C. Mielczarski, P. Nehring, and A. Smuszkiewicz. 2011. Wyzwania 
współczesnej kultury wobec retoryki-wielogłos [Challenges of contemporary culture against rhetoric-Multiple voice]. Forum Artis Rhetoricae 2(25): 15-38.

Bogołębska B. 2006. Konteksty stylistyczne i retoryczne [Stylistic and rhetorical contexts]. Łódź Piktor.

Bryniarski, E., Z. Bonikowski, J. Waldmajer, and U. Wybraniec-Skardowska. 2011. Realistic premises of epistemic argumentation for dynamic epistemic logics. Studies in Logic, Grammar and Rhetoric 23 (36): $173-187$.

Budzynska K. 2011. Araucaria-PL: Software for teaching argumentation theory. Proceedings of the 3rd International Congress on tools for teaching logic (TICTTL 2011), LNAI 6680, 30-37. New York: Springer.

Budzynska K. 2013. Circularity in ethotic structures. Synthese, 190(15): 3185-3207, 2013. First published in 2012 under Open Access: DOI 10.1007/s11229-012-0135-6.

Budzynska, K., K. Debowska-Kozlowska, M. Kacprzak, and M. Załęska. 2012. Interdyscyplinarność w badaniach nad argumentacją i perswazją [Interdisciplinarity in the studies on argumentation and persuasion]. In Interdyscyplinarnie o interdyscyplinarności, eds. A. Chmielewski, M. Dudzikowa, and A. Grobler, 147-166, Krakow: Impuls.

Budzynska, K., M. Kacprzak, and P. Rembelski. 2009. Perseus. Software for analyzing persuasion process. Fundamenta Informaticae 93(1-3): 65-79.

Budzynska, K., F.H. van Eemeren, and M. Koszowy, eds. 2014. Studies in Logic, Grammar and Rhetoric, Special issue on Pragmatics and Dialectics of Argument, Vol. 36(49).

Budzynska, K., and M. Witek. 2014. Non-inferential aspects of ad hominem and ad baculum. In Argumentation, special issue "The Polish School of Argumentation", eds. K. Budzynska and M. Koszowy, Vol. 3, this issue.

Cap, P. 2013. Proximization: The pragmatics of symbolic distance crossing. Amsterdam-Philadelphia: John Benjamins.

Debowska-Kozlowska K. 2014. Processing topics from the Beneficial Cognitive Model in partially and over-successful persuasion dialogues. In Argumentation, special issue "The Polish School of Argumentation”, eds. K. Budzynska and M. Koszowy, Vol. 3, this issue.

Dignum, F., B. Dunin-Kȩplicz, and R. Verbrugge. 2001. Creating collective intention through dialogue. Logic Journal of the IGPL 9: 145-158.

Dobrosielski. M. 1957. Logika i retoryka [Logic and rhetoric]. Warszawa.

Domański, H., M. Federowicz, A. Pokropek, D. Przybysz, M. Sitek, M. Smulczyk, and T. Źółtak. 2012. From school to work: Individual and institutional determinants of educational and occupational career trajectories of young Poles. ASK: Research \& Methods 21(1): 123-141.

Dunin-Kȩplicz, B., and A. Strachocka. 2013. Perceiving rules under incomplete and inconsistent information. In Computational logic in multi-agent systems, Lecture Notes in Computer Science, Vol. 8143, 256-272.

Dunin-Kȩplicz, B., and R. Verbrugge. 2010. Teamwork in multi-agent systems: A formal approach. New York: Wiley.

Dziubiński, M., and S. Goyal. 2013. Network design and defence. Games and Economic Behavior 79(1): $30-43$.

Garbacz, P., P. Kulicki, and R. Trypuz. 2012. A formal ontology of knowing and knowledge. Knowledge Management Research \& Practice 10: 206-226.

Gizbert-Studnicki, T. 2010. The burden of argumentation in legal disputes. Ratio Juris 3(1): 118-129.

Gomolińska. A. 2005. On rough judgment making by socio-cognitive agents. In Proceedings of the 2005 IEEE//WIC//ACM International Conference on Intelligent Agent Technology (IAT'2005), eds. A. Skowron et al., 421-427, Los Alamitos, CA. IEEE Computer Society Press.

Górski J. 1559. De generibus dicendi liber. Krakow.

Grabowski, A. 1999. Judicial argumentation and pragmatics: A study on the extension of the theory of legal argumentation. Krakow: Księgarnia Akademicka.

Grabowski, A. 2003. Sonderfallthese-its critique and interpretation. Rechtstheorie 34: 371-392.

Groarke L. 2013. Informal logic. The Stanford Encyclopedia of Philosophy, Winter 2003 Edition. http://plato.stanford.edu/entries/logic-informal/.

Hołówka, T. 1998. Błędy, spory, argumenty [Fallacies, disputes, arguments]. Warszawa: Wydział Filozofii i Socjologii Uniwersytetu Warszawskiego.

Hołówka T. 2007. Kultura logiczna w przykładach [Logical education in examples]. Warszawa: PWN.

Jochemczyk, Ł., and A. Nowak. 2010. Constructing a network of shared agreement: A model of communication processes in negotiations. Group Decision and Negotiation 19(6): 591-620. 
Kacprzak M., M. Dziubiński, and K. Budzynska. 2014. Strategies in dialogues: A game-theoretic approach. In Frontiers in Artificial Intelligence and Applications. Proc. of 5th International Conference on Computational Models of Argument COMMA 2014, IOS Press, accepted for publication.

Kacprzak, M., and A. Sawicka. 2014. Identification of formal fallacies in a natural dialogue. Fundamenta Informaticae 133: 1-15.

Kacprzak, M., and O.Yaskorska. 2014. Dialogue protocols for formal fallacies. In Argumentation, special issue "The Polish School of Argumentation”, eds. K. Budzynska and M. Koszowy, Vol. 3, this issue.

Kawalec, P. 2003. Structural reliabilism: Inductive logic as a theory of justification. Dordrecht: Kluwer.

Kawalec, P. 2012. Bayesianizm w polskiej tradycji probabilizmu-studium stanowiska Kazimierza Ajdukiewicza [Bayesianism in the Polish tradition of probabilism: A study of Kazimierz Ajdukiewicz's conception]. Ruch Filozoficzny 1: 111-122.

Kielar, M. 2011. Transitivity as a marker of valuation in journalistic discourse. In On Words and Sounds: A Selection of Papers from the 40th PLM, ed. K. Debowska-Kozlowska, and K. DziubalskaKołaczyk, 311-322. Newcastle upon Tyne: Cambridge Publishing.

Kisielewicz. A. 2011. Sztuczna inteligencja i logika [Artificial Intelligence and Logic]. Warszawa: WNT.

Konarski. S. 1767. O sztuce dobrego myślenia do sztuki dobrej wymowy [On the art of good thinking and good speech]. In Pisma wybrane, ed. J. Nowak-Dłużewski, Vol. 2.

Koszowy. M, ed. 2009. Studies in Logic, Grammar and Rhetoric, Special Issue on Informal Logic and Argumentation Theory, Vol. 16(29).

Koszowy. M, ed. 2011. Studies in Logic, Grammar and Rhetoric, Special Issue on Argument and Computation, Vol. 23(36).

Koszowy, M., and M. Araszkiewicz. 2014. The Lvov-Warsaw School as a source of inspiration for argumentation theory. In Argumentation, special issue "The Polish School of Argumentation", eds. K. Budzynska and M. Koszowy, Vol. 3, this issue.

Kublikowski. R. 2009. Definition within the structure of argumentation. In Studies in Logic, Grammar and Rhetoric, Special Issue on Informal Logic and Argumentation Theory, ed. M. Koszowy, Vol. 16 (29), 229-244.

Kuzio, A. 2014. The exploitation of schemata in persuasive and manipulative discourse in Polish, English and Russian. Newscastle-upon-Tyne: Cambridge Scholar Publishing.

Lewiński, P. 2012. Neosofistyka. Argumentacja retoryczna $w$ komunikacji potocznej [Neosophistry. Rhetorical argumentation in every day communication]. Wrocław: Wydawnictwo Uniwersytetu Wrocławskiego.

Lichański. J. 2003. Retoryka w Polsce. Studia o historii, nauczaniu i teorii w czasach I Rzeczypospolitej [Rhetoric in Poland. Studies on history, teaching and theory in times of the First Republic of Poland]. Warszawa: DiG.

Malinowski, J. 2003. Pragmatic interpretation of utterances. Logic and Logical Philosophy 11: 115-127.

Małuszyński, J., and A. Szałas. 2013. Partiality and inconsistency in agents belief bases. KES-AMSTA, Frontiers of Artificial Intelligence and Applications 252: 3-17.

Marciszewski, W. 1994a. Logic from a Rhetorical Point of View. Berlin: De Gruyter.

Marciszewski, W. 1994b. Sztuka rozumowania $w$ świetle logiki [The art of reasoning from the perspective of logic]. Warszawa: Aleph.

Mayakowska, M. 1936. Klasyczna teoria wymowy [Classic theory of speech]. Warszawa.

Nieznański, E. 2010. Sylogizm prawniczy z logicznego punktu widzenia [Legal syllogism from the point of view of logic]. Edukacja prawnicza 3: 15-16.

Nowak, L. 1973. Interpretacja prawnicza: problemy metodologiczne [Legal Interpretation: Methodological Problems]. Warszawa: PWN.

Patryas, W. 1988. Interpretacja karnistyczna. Studium metodologiczne [Penal-Legal Interpretation. A Methodological Study]. Poznań: Wydawnictwo Naukowe UAM.

Pawlak, Z. 1982. Rough sets. International Journal of Parallel Programming 11(5): 341-356. doi: 10.1007/BF01001956.

Peczenik, A. 1966. Wartość naukowa dogmatyki prawa: praca z zakresu porównawczej metodologii nauki prawa [The Scientific Value of Legal Science: A Work in Comparative Methodology of Legal Science]. Krakow: Uniwersytet Jagielloński.

Peczenik, A. 1988. Legal reasoning as a special case of moral reasoning. Ratio Juris 1: 123-136.

Peczenik, A. 2008. On law and reason, 2nd ed. (with preface by Jaap C. Hage). New York: Springer.

Peczenik, A. , Wróblewski. J. 1985. Fuzziness and transformations: Towards explaining legal reasoning. Theoria LI:24-44. 
Pelc, J. 1969. Meaning as an instrument. Semiotica 1(1): 26-98.

Pelc, J. 1970. A functional approach to the logical semiotics of natural language. In Sign, Language, Culture, 89-112.

Pogonowski, J. 2011. Operacje na argumentacjach [Operations on arguments]. Investigationes Linguisticae XXIII:148-169.

Pogonowski, J. 2012. Kilka uwag o intuicji matematycznej [A few remarks about mathematical intuition]. Filozofia Nauki 2(78): 107-113.

Puczyłowski, T. 2012. O argumentacji odwołującej się do implikatury konwersacyjnej [On argumentation appealing to conversational implicature]. Przeglad Filozoficzny 3(83): 93-110.

Rytel, J. 2012. Reaching an agreement: Argumentation in preschoolers' narrative discourse. Warszawa: Wydawnictwo Uniwerstytetu Kardynała Stefana Wyszyńskiego.

Searle, J. 1969. Speech Acts: An essay in the philosophy of language. Cambridge: Cambridge University Press.

Selinger. M. 2014. Towards formal representation and evaluation of arguments. In Argumentation, special issue "The Polish School of Argumentation", eds. K. Budzynska and M. Koszowy, Vol. 3, this issue.

Skowron, A., M.K. Chakraborty, J.M. Grzymala-Busse, V.W. Marek, S.K. Pal, J.E. Peters, G. Rozenberg, D. Slezak, R. Slowinski, S. Tsumoto, A. Wakulicz-Deja, G. Wang, and W. Ziarko. 2013. Professor Zdzisław Pawlak (1926-2006): Founder of the Polish School of Artificial Intelligence. In Rough sets and Intelligent systems. Professor Zdzislaw Pawlak in Memoriam, series intelligent systems reference library, eds. Andrzej Skowron and Zbigniew Suraj, Vol. 42, 1-56. New York: Springer.

Skulska. J. 2013. Schematy argumentacji Waltona jako metodologiczna podstawa analizy języka nauk politycznych w płaszczyźnie bezpieczeństwa państwa [Walton's argumentation schemes as a methodology for analysing language of political sciences]. In Studia Bezpieczeństwa Narodowego [National Security Studies], eds. A. Warchał and C. Sońta, Vol. 4.

Skwara. M. 2006. Retoryka w Polsce. Teoria i praktyka w ostatnim półwieczu [Rhetoric in Poland. Theory and practice in the last half a century]. Szczecin: Uniwersytet Szczeciński.

Smolak M. 2003. Uzasadnianie sądowe jako argumentacja z moralności politycznej. O legitymizacji władzy sędziowskiej [Judicial justification as a moral-political argumentation]. Krakow: Zakamycze.

Sokół M. 2010. Questions and the authors' self-presentation in academic electronic discourse. In Komunikacja międzyludzka. Leksyka. Semantyka, Pragmatyka, eds. E. Komorowska, K. KondziołaPich, and E. Panter, 235-241, Szczecin: Volumina.

Sowińska, A. 2013. A critical discourse approach to the analysis of values in political discourse: The example of freedom in President Bushs State of the Union addresses (2001-2008). Discourse \& Society 24(6): 792-809.

Stalmaszczyk, P. 2013. Interdyscyplinarne i metodologiczne inspiracje w językoznawstwie strukturalnym i generatywnym [Interdisciplinary and methodological inspirations in structural and generative linguistics]. Przegląd Humanistyczny 5: 39-49.

Stawecki T. 2012. Argument against absurdity of legal reasoning-Fundamental, subsidiary or rhetoric? In Argumentation 2012. International Conference on Alternative Methods of Argumentation in Law, eds. M. Araszkiewicz, M. Myska, T. Smejkalova, J. Savelka, and M. Skop, 89-103, Brno: Masarykova univerzita.

Stepaniuk, J. 2008. Rough-granular computing in knowledge discovery and data mining. New York: Springer.

Suchoń, W. 2005. Prolegomena do retoryki logicznej [Prolegomena to logical rhetoric]. Krakow: Jagiellonian University Press.

Suchoń, W. 2008. Teoretyczne problemy logiki praktycznej [Theoretical problems of practical logic]. Krakow: Jagiellonian University Press.

Szymanek, K. 2001. Sztuka argumentacji. Słownik terminologiczny [The art of argument: A terminological dictionary]. Warszawa: PWN.

Szymanek, K. 2009. Argument z podobieństwa [Argument by similarity (analogy)]. Katowice: University of Silesia Press.

Tokarz, M. 1985. Goals, results and efficiency of utterances. Bulletin of the Section of Logic 14(4): 150155.

Tokarz, M. 1987. Persuasion. Bulletin of the Section of Logic 16(1): 46-49.

Tokarz, M. 2006. Argumentacja, perswazja, manipulacja [Argumentation, persuasion, manipulation]. Gdańsk: Gdańskie Wydawnictwo Psychologiczne.

Tomczyk, J. 2011. Civil society: historia pojęcia, znaczenie idei [Civil society: History of the notion, significance of the idea]. In Tolerancja, eds. A. Rosół and M.S. Szczepański, 46-51. 
Trybulec, A. 1978. The Mizar-QC/6000 logic information language. ALLC Bulletin, 6(2): 136-140.

Urbański, M. 2001. Synthetic tableaux and erotetic search scenarios: Extension and extraction. Logique et Analyse 173: 69-91.

Urbański, M. 2009. Trzy modele rozumowań abdukcyjnych [Three models of abductive reasoning]. In Funkcje umystu. Poznańskie Studia z Filozofii Humanistyki, eds. M. Urbański and P. Przybysz, Vol. 8(21), 303-315.

van Eemeren, F.H., B. Garssen, B. Verheij, E.C.W. Krabbe, A.F. Snoeck Henkemans, and J.H.M. Wagemans. 2015. Handbook of argumentation theory. New York: Springer.

Walton, D., and E. Krabbe. 1995. Commitment in Dialogue: Basic Concepts of Interpersonal Reasoning. New York: State University of N.Y. Press.

Wasilewska-Kamińska. E. 2014. Myślenie krytyczne jako cel ksztatcenia w systemach edukacyjnych USA $i$ Kanady. Analiza wybranych programów i metod nauczania myślenia krytycznego. [Critical Thinking as an Educational Goal in the USA and Canada. The Analysis of Selected Critical Thinking Instruction Methods. (Implications for Polish Education)]. Unpublished doctoral dissertation, University of Warsaw.

Wieczorek K.A. 2007. Dlaczego wnioskujemy niepoprawnie. Teoria modeli mentalnych P.N. JohnsonaLairda [Why do we make mistakes in our reasoning. Johnson-Laird's theory of mental models]. Filozofia Nauki 4:111-134.

Wieczorek K.A. 2013. Argumenty równi pochylej. Analiza z perspektywy logiki nieformalnej [Slippery slope arguments. The analysis from the perspective of informal logic]. Katowice: University of Silesia Press.

Wiśniewski, A. 1996. The logic of questions as a theory of erotetic arguments. Synthese 109(1): 1-25.

Witek, M. 2013. How to establish authority with words. In Theory of imperatives from different points of view, eds. A. Brozek et al., Vol. 2, 145-157.

Wójcicki, R. 1997. The postwar panorama of logic in Poland. In Logic and Scientific Methods, eds. M.L. Dalla Chiara et al., 497-508. New York: Kluwer.

Woleński, J. 1972. Logiczne problemy wykładni prawa [Logical Problems of Legal Interpretation]. Krakow: Uniwersytet Jagielloński.

Woleński J. 2013. Lvov-Warsaw School. The Stanford Encyclopedia of Philosophy, Winter 2003 Edition. http://plato.stanford.edu/entries/lvov-warsaw/.

Woleński, J., and S. Lapointe. 2009. Introduction. In The Golden Age of Polish Philosophy: Kazimierz Twardowski's Philosophical Legacy, eds. S. Lapointe, J. Woleński, M. Marion, and W. Miskiewicz, 1-16. Dordrecht: Springer.

Wróblewski, J. 1992. The judicial application of law. New York: Springer.

Wybraniec-Skardowska U. 2010. Wyróżnione zasady argumentacyjne w dyskursie politycznym [Certain argument principles in political discourse]. In Dialogikon, eds. W. Suchoń and D. Kowalski, Vol. $15,19-34$.

Yaskorska, O., K. Budzynska, and M. Kacprzak. 2013. Proving propositional tautologies in a natural dialogue. Fundamenta Informaticae 128(1-2): 239-253.

Załęska, M. 2011. Ad hominem in the criticisms of expert argumentation. In Proceedings of the 7th Conference of the International Society for the Study of Argumentation, ed. F.H. van Eemeren, B. Garssen, D. Godden, and G. Mitchell, 2047-2057, Amsterdam: Sic Sat.

Załęska M. 2012. Rhetoric and politics: Central/Eastern European perspectives. Cambridge: Cambridge Scholars Publishing.

Zieliński, M., Ziembiński, Z. 1988. Uzasadnianie twierdzeń, ocen i norm w prawoznawstwie [Justification of statements, values and norms in jurisprudence]. Warszawa: PWN.

Ziembiński, Z. 1955. Logika praktyczna [Practical logic]. Warszawa: PWN.

Ziembiński, Z. 1966. Logiczne podstawy prawoznawstwa: wybrane zagadnienia [The Logical Foundations of Jurisprudence: Selected Issues]. Warszawa: Wydawnictwo Prawnicze. (English edition: Practical Logic, Dordrecht: D. Reidel Pub. Co, 1976).

Ziomek, J. 1990. Retoryka opisowa [Descriptive rhetoric]. Wroclaw: Ossolineum.

Żurek, T., and M. Araszkiewicz. 2013. Modelling teleological interpretation. In Proceedings of the 14th International Conference on Artificial Intelligence and Law (ICAIL 2013), ed. E. Francesconi, and B. Verheij, 160-168. New York: ACM. 